SESSION I

\title{
Roles and responsibilities; facilitation and cooperation
}


